\title{
Review
}

\section{The undiscovered Dewey: Religion, morality, and the ethos of democracy}

\author{
Melvin L. Rogers \\ Columbia University Press, New York, 2009, xxi + 328pp., $\$ 50.00 / £ 34.50$, \\ ISBN: 978-0231144865
}

Contemporary Political Theory (2012) 11, e12-e14. doi:10.1057/cpt.2011.9

In the introduction to this careful, comprehensive and rich book, Melvin Rogers defends his bold title claim through a musical reference: just as a different arrangement of familiar elements helps us experience music anew, so his reframing of familiar elements of Dewey's thought brings forth aspects that, in his words, have been 'overlooked, underappreciated or denied' (p. 14). The analogy is apt. Even if the Dewey Rogers gives us is not undiscovered exactly, it is certainly one marked by a fullness, richness and nuance that comes from foregrounding the concept of contingency in Dewey's approach to inquiry, religion, morality and democracy.

Rogers accomplishes this by situating Dewey's middle and later works against a horizon of responses to Charles Darwin among late nineteenth century Protestant theologians. In Rogers' stylized intellectual history, Charles Hodge stands in for conservative Protestants, who see Darwinism as a denial of God's sovereignty and a symptom of the age's spiritual sickness, whereas Henry Ward Beecher stands in for liberal Protestants, who incorporate Darwinism into a progressive account of God's redemptive work in history. Dewey cannot abide by the epistemological confidence of the liberals, who in his view do not take seriously enough the challenges Darwinism posed to the question of human agency. Whereas the conservatives rightly recognize the depth of this challenge, Dewey cannot accept their fideistic solution and ultimate dismissal of Darwinism. He instead forges a third way that embraces contingency as the starting point for a practice of situated inquiry whose orientation is consistent with what Rogers calls Dewey's 'religious naturalism'.

Rogers examines Dewey's religious naturalism at length in the central and most interesting chapter of the book. He contends that Dewey, like Emerson, seeks to open up religious experience to beliefs, institutions and objects that lack supernatural warrant. Dewey does this by distinguishing piety and faith, on the one hand, from the objects to which they are attached, on the other hand. Piety for Dewey is a virtue of retrospective reflection on

(C) 2012 Macmillan Publishers Ltd. 1470-8914 Contemporary Political Theory Vol. 11, 3, e12-e14 www.palgrave-journals.com/cpt/ 
our narrative of experience, including the traditions in which we stand. Piety orients us to the past, although not in a mode of blind deference. Rather, it involves an ongoing critical inquiry into, and assessment of, the past as a means of integrating one's self and the world. In Rogers' words, 'piety involves an evaluative moment of attunement - a taking stock of resources in relation to one's life and fortune' (p. 131). As an appraisal of what is ready-at-hand, piety allows tradition to aid but not determine one's journey.

Piety's counterpart, faith, is forward- rather than backward-looking. Faith is a virtuous practice of projecting possibilities, a commitment to ideals that help unify the self and orient it in future action. In Dewey's account, however, these ideals are not reified so as to be beyond the possibility of revision. Instead, they are always revisable by virtue of their impact on practical action and by what the world allows. As he does with piety, then, Rogers is keen to attach Dewey's understanding of faith back to inquiry, but whereas the inquiry at the heart of piety can review past resources, the inquiry at the heart of faith lacks such evidentiary support. The ideals of faith always run ahead of evidence. The authority the ideals possess, in other words, is never exhausted in the discovery of evidence that would support assent to them. This runningahead quality is what makes faith both difficult and courageous.

Given these accounts of piety and faith, Dewey's notion of identity is thus one in which we are neither wholly defined by the past nor are we mere unencumbered selves. Our pious allegiances help shape us through critical, retrospective narration, and the contingent, revisable ideals of faith guide us as we move forward. This is Dewey's response to the crisis of agency brought about by Darwin. The picture of Dewey Rogers gives to us here is very appealing, one not wedded to a positivist account of knowledge and an attendant disparagement of religion. Not only that, the picture of the intertwining of piety, faith, inquiry and identity is itself highly appealing, as is demonstrated in Rogers' final two chapters on morality and politics, which call for intelligent sympathy toward others and mutual responsiveness in the form of giving reasons. In this picture, Deweyan citizens have sufficient grounds and ideals for engaging in deliberation and action, but they do so with an awareness of the contingency of these grounds and an openness toward the results of ongoing inquiry. These are, then, citizens ideally suited for democratic politics.

It is not always clear from Rogers' book whether this is a phenomenological account of religion - that this is just the way faith and piety necessarily work, in Dewey's view - or whether this is a normative account - that this is the way faith and piety ought to work to fit Dewey's social and democratic theory. In Rogers' telling, Dewey's approach to religion means that the objects of our allegiance are always part of the public giving and demanding of reasons that is at the heart of both inquiry and deliberation. In short, we have to answer for 
these allegiances. As Rogers rightly points out, this means that Dewey would escape the problem of how to draw the lines that exclude religion from public debate, as Rawls, Habermas and other theorists of public reason have felt compelled to do in recent decades. Religious commitments need not be excluded from public debate for Dewey; indeed, excluding them would actually impede inquiry and deliberation.

If this is a normative account of how faith and piety ought to work, we are back to the problems of how a democratic polity encourages these religious modes and of what is to be done with respect to religions that do not fit this picture. Can religious citizens who do not practice piety and faith in Dewey's contingent, inquiry-oriented mode also be good deliberative citizens? What if their piety is not experienced as including the (at least minimal) distance from their traditionary practices that would be necessary for the critical assessment Dewey calls for? What if the ideals of their faith are not seen by them as revisable?

Rogers seems to want this to be a phenomenological account, one necessitated by and arising out of our modern condition. Modernity, he argues, does not require the demise of religious commitments nor that these commitments be regarded as presumptively irrational, but it does mean that 'a theological framework no longer serves as a unifying background from which we advance our claims' (p. 135). This situation is what necessitates the giving of reasons. However, the presence or absence of a unifying theological background is not simply a matter of sociological description; such descriptions are also always political claims and political projects. Certainly, among the challenges facing American democracy today are attempts to lay claim to a unifying background as necessary to the health and survival of the polity and as a means of demarcating who belongs and who does not. The political project of defining this background is revealed in claims that the United States is a 'Christian' or 'Judeo-Christian' nation, claims that imagine the nation as non-atheistic and (increasingly, it seems) non-Muslim.

My concern here is that lurking in the background of Dewey's approach to religion is an account of secularization that Rogers does not make explicit. This presumed secularization framework depends on religious believers incorporating differentiated sources of authority into their own religious worldviews. This, in turn, would mean that only those religions that incorporate these differentiated claims would be open to the practices of inquiry and deliberation that Dewey demands and on which he sees democracy depending.

Darren Walhof

Grand Valley State University, Allendale, Michigan 49401, USA walhofd@gvsu.edu 